The Research Journal of the Costume Culture

[Original Article]

Received May 03, 2017

Revised May 30, 2017

Accepted June 07, 2017

${ }^{\dagger}$ Corresponding author

(danaesuh@mju.ac.kr)

ORCID

Seol Young Oh

http://orcid.org/0000-0002-4648-6080

Dongae Suh

http://orcid.org/0000-0003-0627-0805

This research was supported

by the research fund of

Myongji University in 2016.
pISSN 1226-0401

eISSN 2383-6334

RJCC Vol.25, No.3, pp.270-284, June 2017

https://doi.org/10.7741/rjcc. 2017.25.3.270

\section{Producing the insoles for flat feet of senior men using 3D systems based on 3D scanning, 3D modeling, and 3D printing}

\author{
Seol Young Oh and Dongae $\mathrm{Suh}^{\text {*† }}$ \\ Symbiotic Life-TECH, Yonsei University, Korea \\ Dept. of Design, Myongji University, Korea ${ }^{*}$
}

\section{D 스캐닝, 3D 모델링, 3D 프린팅 기반의 3D 시스템에 의한 시니어 평발용 인솔 제작}

\author{
오 설 영·서 동 애 ${ }^{*+}$
}

연세대학교 심바이오틱 라이프텍 연구원, 명지대학교 디자인학부

\begin{abstract}
This study aimed to create 3D-printed insoles for flat-footed senior men using 3D systems. 3D systems are product-manufacturing systems that use 3-dimensional technologies like 3D scanning, 3D modeling, and 3D printing. This study used a 3D scanner (NexScan2), 3D CAD programs including Rapidform, AutoCAD, SolidWorks, Nauta+ compiling program, and a 3D printer. In order to create insoles for flat-footed senior men, we analyzed horizontal sections of 3D foot scans We selected 20 flatfooted and 20 normal-footed subjects. To make the 3D insole models, we sliced nine lines on the surface of the subjects' 3D foot scans, and plotted 144 points on the lines. We calculated the average of these $3 \mathrm{D}$ coordinates, then located this average within the $3 \mathrm{D}$ space of the AutoCAD program and created 3D sole models using the loft surface tools of the SolidWorks program. The sole models for flat feet differed from those of normal feet in the depth of the arch at the inner sideline and the big toe line. We placed the normal-footed sole model on a flat-footed sole model, and the combination of the two models resulted in the 3D insole for flat feet. We printed the $3 \mathrm{D}$ modeled insole using a $3 \mathrm{D}$ printer. The $3 \mathrm{D}$ printing material was an acrylic resin similar to rubber. This made the insole model flexible and wearable. This study utilized 3D systems to create 3D insoles for flat-footed seniors and this process can be applied to manufacture other items in the fashion industry as well.
\end{abstract}

Keywords: $3 D$ foot scan( $3 D$ 발 스캔), $3 D$ solid modeling( $3 D$ 솔리드 모델링), $3 D$ printing( $3 D$ 프린팅), flat feet(평발), insoles(인솔)

\section{Introduction}

발에는 인체를 지지하고 모든 체중을 받쳐주며, 보행 시 충격을 흡수하고 분산시 
키는 완충 역할을 할 수 있도록 수많은 인대, 골격, 근육들이 접합, 배열되어 있다. 발바닥의 뼈들은 체중 을 분산시키기 위해 활같이 휘어져 아치를 형성하고 있으며, 발 아치와 지면사이의 공간은 에어펌프의 역 할을 하여 보행 시 충격을 완화하고, 체중이 한 부분 에 집중되지 않게 분산시킨다(Kim, 2001; Kim, 2003; Park et al., 2009). 발아치의 형태가 비정상적이면 걸 을 때 발의 피로감이 증가하고, 균형 감각이 떨어져 운동 능률이 저하된다. 정상적인 발아치의 높이는 $2.3 \mathrm{~cm}$ 정도이며, 정상보다 발아치가 낮으면 평발, 높 으면 오목발로 분류된다(Jang, 2012).

평발은 발아치가 비정상적으로 낮아지거나 소실되 어 발바닥 안쪽이 편평하게 변형된 상태로, 아치를 통한 충격 흡수가 어려워 몸 전체에 피로감을 주며, 장시간 보행 시 통증을 느낀다(Flatfoot, n.d.). 나이가 들면서 나타나는 노화, 체중 증가, 생활 습관 등으로 발아치 유지를 돕는 힘줄과 뼈를 받쳐주는 근육 및 인대가 퇴화하면서 아치가 내려앉게 되어 발볼이 넓 어지고, 발바닥이 평평해져 평발의 비율이 증가하게 된다. 평발은 정상발에 비해 중족부에서 발과 바닥과 닿는 접지 면적이 많기 때문에 보행 장애가 나타나게 되는데, 평발에 인솔을 삽입하면 정상발과 유사한 발 아치의 형태가 만들어지면서 정상적인 접지 면적이 형성되고, 발 전체로 압력 분산이 되어 정상 보행이 가능하게 된다(Kim, 2011).

의학 분야에서는 의사의 문진과 방사선 사진 촬영 으로 발바닥을 이루는 뼈와 관절의 각도로 평발을 진 단하는데 비해, 신발 및 신발 보조용품 분야에서는 정상발과 평발의 분류를 위해 지면과 닿는 발 바닥면 의 $2 \mathrm{D}$ 이미지를 수집하여 분석하는 방법이 주로 사 용된다. 기존에는 잉크를 묻힌 발을 족문기에 올려놓 고, 발바닥 지문을 찍어 중족부의 형태를 분석하거나 (Coughlin \& Kaz, 2009; Kang, 2012; Kim, 2001; $\mathrm{Kim}, 2003$; Kim, 2011), 아크릴 판 아래에 평판스캐 너를 놓고 발바닥면의 2D 이미지를 스캔하는 방법이 주로 사용되었다(Kim, 2013; Park, 2005). 최근에는 기존의 잉크를 사용한 발 지문 측정 방법을 보완하 여, 3D 발 스캔 데이터로부터 디지털 발 지문을 수집 하는 방법이 시도되고 있으며(Lee, Lin, \& Wang, 2014), 기술이 발전할수록 발바닥 데이터의 수집은 $3 \mathrm{D}$ 스캐 닝 기반으로 발전할 것으로 예상된다.
발 지문 데이터를 수집한 선행 연구들을 살펴보면, 동적 발 지문을 찍을 때는 족문기에 오른쪽 발을 얹 고 체중 전체를 오른쪽 발에 옮긴 후, 수 초간 상태를 유지하였다가 천천히 발을 떼어내었을 때 찍힌 발바 닥의 잉크 자국을 사용하고(Coughlin \& Kaz, 2009; $\mathrm{Kim}, 2001 ; \mathrm{Kim}, 2003)$, 정적 발 지문을 찍을 때는 족문기 위에 발을 올린 상태에서 무릎을 2번 구부렸 다가 핀 후 발을 떼어내어 발바닥 전체에 체중의 압 력이 충분히 가해져 발 지문이 선명하게 찍힐 수 있 도록 한다(Kang, 2012). 그러나 3D 발 스캐너는 오른 쪽 발을 스캐너 안에 넣고 체중을 양쪽 발에 골고루 분산시킨 상태에서 발의 $3 \mathrm{D}$ 형상을 수집하게 되는데, 이 경우 체중이 분산되기 때문에 족문기로 동적 및 정적 발 지문을 측정한 경우보다 지면과 발바닥이 닿 는 면이 적게 나타난다. 따라서 발아치 유형 분류를 위해 $3 \mathrm{D}$ 발 형상을 분석할 때 바닥면과 $3 \mathrm{D}$ 스캔 형 상 데이터가 맞닿은 접지면의 형상만을 관찰하는 것 은 측정 시 가해진 체중의 힘이 다르기 때문에 적합 하지 않다. 이를 보완하기 위해 Lee et al.(2014)은 3D 발 스캔 데이터로부터 디지털 발 지문 데이터를 수집 할 때, 접지면이 아니라 바닥면에서 $1.5 \mathrm{~mm}$ 올라간 수평면을 기준으로 발의 3D 메쉬 표면과 만나는 윤 곽선을 따라 발 지문을 그린 후, AutoCAD 프로그램 에서 치수를 측정하였다. 그러나 $3 \mathrm{D}$ 스캔 데이터로부 터 2D 발 지문을 수집한 연구가 아직 많지 않아, 발 바닥 면 수집을 위한 수평면의 최적 위치에 대한 더 많은 논의가 필요하다.

수집한 발바닥 데이터에서 발바닥 편평도를 파악 하는 방법 또한 다양하다. 발 지문에서 전족 폭에 대 한 중족 폭 비율을 지수로 나타낸 Chippaux-Smirak Index(CSI)이나 발 지문의 후족 폭에 대한 중족 폭 비 율 지수인 Stahelis Arch Index(SAI)를 사용하기도 하 며(Kang, 2012), 전족부, 중족부, 후족부의 면적을 각 각 측정하고 발바닥 전체의 면적에 대한 중족부 면적 비율인 Arch Index(AI)를 구하기도 한다(Murley, Menz, \& Landorf, 2009). 발 안쪽 점과 발뒤꿈치 안쪽 점을 연결한 스탈크선(Stalk line)과 세 번째 발가락과 발뒤 꿈치 중심을 연결한 마이어선(Meyer line)을 긋고, 이 두 선의 이등분선과 발바닥 지문이 닿는 정도에 따라 발의 평발을 판정하는 Meyer \& Stalk 방법도 사용된 다(Choi, 2005). 
인솔(insole)은 신발 안쪽에서 발을 받쳐주는 중창 부분을 말하며, 발바닥 형태로 제작되는 경우가 대부 분이다(Jang, 2012). 한국 산업 규격의 구두용 조립식 중창규격(KS G 3406: 1994)에 따르면(Korean Agency for Technology and Standards, 2014), 인솔은 평균 체 중을 지탱할 수 있는 충분한 강도와 견고성을 지녀야 하며, 하중을 반복적으로 연쇄 순환시킬 수 있는 탄 력성을 지니고, 보행 시 추진력과 착용 시 안정감을 주어야 한다. 이러한 인솔은 발바닥과 신발 사이에서 착화감을 높이는 쿠션 역할을 하며, 발바닥에 가해지 는 압력 하중을 효율적으로 분산시켜 보행에 도움을 주는 의료 보조 기구의 역할을 한다(Song, Kim, Kim, $\&$ Lee, 2016). 보조기구용 인솔은 외적인 요인에 의 하여 변형된 발에 이상적인 발아치를 제공한다. 적합 한 용도의 인솔을 착용하면 변형된 발 뼈, 인대, 근육 등의 구조가 정상적으로 바뀌어 자세를 바르게 유지 하고, 발에 가해지는 충격을 흡수함으로써 발은 물론 몸 전체의 피로감을 감소시킬 수 있다(Park et al., 2009). 발 아치에 쿠션을 주는 기능성 인솔을 착용하 면 족압의 접촉 면적이 높아지고, 근육피로도가 낮아 지며 착용자의 만족도가 높아진다(Min et al., 2016). 국 내 인솔 업체에는 기능성 인솔, 스포츠용, 평발 교정 용, 충격흡수용 인솔 등, 다양한 용도의 제품들을 생 산하고 있으나, 축적된 전문 기술과 정량적 데이터를 기반으로 개발된 제품들이 아니기 때문에 제품의 성 능 및 효과에 대한 신뢰성은 아직 낮은 편이다(Kim, 2015).

의학의 발전으로 인해 전 세계가 고령화 사회로 접 어들면서, 시니어(senior) 세대의 건강과 삶의 질 향상 은 중요한 이슈이다. 발은 성, 연령, 체형, 보행 습관 에 영향을 받는데, 고령자의 경우 근육 퇴화 및 장기 간의 신발 착용으로 발 변형이 발생한다(Kim, 2013). 노화가 진행되면 발바닥 지방층이 얇아지고 발아치 가 내려가게 되어, 발의 피로를 쉽게 느끼고 여러 종 류의 발 질환을 겪게 된다. 매년 65 세 이상 고령자의 $30 \%$ 가 낙상을 경험하는데, 노화로 인한 생리적 요인 이나 질병과 같은 내적 요인뿐만 아니라 부적절한 보 행 보조기 및 신발 착용과 같은 외적 요인이 복합적 으로 상호작용하여 치명적인 낙상을 일으키는 것으 로 보고되고 있다(Lee et al., 2007). 따라서 시니어 세 대의 발 형태를 실증적으로 반영한 인간공학적 인솔
제품의 개발 및 보급이 시급하다.

$3 \mathrm{D}$ 스캐너와 $3 \mathrm{D}$ 프린터와 같은 $3 \mathrm{D}$ IT 기술이 비약 적으로 발달함에, 따라 신발 및 발 연구 분야에서도 $3 \mathrm{D}$ 시스템이 활발히 적용되고 있다. 2005년 제5차 및 2010년 제6차 한국인 인체치수 조사사업(SizeKorea) 은 전 연령대를 대상으로 3 차원 발 스캐너로 수집한 $3 \mathrm{D}$ 형상 데이터와 자동 계측 프로그램으로 측정한 24개 항목의 발 치수 데이터를 산업체와 학계에 제공 하여, $3 \mathrm{D}$ 발 형상 연구가 활발하게 진행되는 기폭제 가 되었다. $3 \mathrm{D}$ 발 스캔 형상 데이터와 $3 \mathrm{D}$ 발 치수를 기 반으로 한 연구는 3D 발 유형 분류(Choi, 2005; Lee \& Kwon, 2008; Leem, Bang, \& Shin, 2007; Seok \& Park, 2007), 3D 스캔 데이터를 이용한 라스트 제작 (Choi, 2015; Lee, 2004; Oh \& Kim, 2013; Shi, Yi, Xiong, \& Jiang, 2009; Xiong, Zhao, Jiang, \& Dong, 2010), 3D 발 형상 분류에 의한 신발 치수체계(Butdee \& Tangchaidee, 2008; Kim, 2013; Park, 2005), 3D 형상을 이용한 신발(Song \& Kim, 2004) 및 인솔개발 (Park et al., 2009) 등 다양한 분야로 발전하였다. 최 근에는 3D 프린팅 인솔(Kim, 2015; Lim, 2016; Song et al., 2016)이나 3D 프린팅 라스트(Oh, Suh, \& Kim, 2016)가 제작되는 등 발 연구 분야에서 3D 프린팅을 통한 연구도 폭넓게 진행되고 있다. 그러나 3D 발 스 캔 데이터를 활용하여 발아치의 곡면 형태를 분석하 고, 이를 제품개발로 연결하는 실증적인 연구는 아직 미비한 실정이다. 한국인 인체치수 조사사업(SizeKorea) 에서는 자동 계측 프로그램을 사용하여 $3 \mathrm{D}$ 스캔한 발 형상에서 부위별 길이, 둘레, 높이, 너비, 각도 치 수를 측정하고 있지만, 발바닥의 아치의 형상을 파악 할 수 있는 치수는 측정 항목에 포함되어 있지 않다. $3 \mathrm{D}$ 발 스캔 데이터를 연구 목적에 맞게 가공하면, 기 존에 발바닥 및 발아치 연구에서 $2 \mathrm{D}$ 이미지의 발 지 문 자료로만 분석해 왔던 방법적 한계를 극복하고, $3 \mathrm{D}$ 발바닥 형상으로부터 $3 \mathrm{D}$ 좌표 측정과 곡률의 정 량적 분석이 가능해질 것이다.

신발제조 분야에서 $3 \mathrm{D}$ 프린터는 이미 상용화 단계 에 있다. 퓨마(Puma)와 리복(Reebok)은 제품 설계에 소요되는 시간을 단축하기 위해 프로토 타입 제작 시 3D 프린터를 사용하고 있으며("How 3D printing", 2013), 나이키(Nike), 아디다스(Adidas), 뉴발란스(New Balance), 언더아머(Under Armor) 등 해외 주요 신발 
브랜드들은 $3 \mathrm{D}$ 프린팅 스포츠화의 상용화 기술을 보 유하고 있다(Benedict, 2016). 특히 3D 시스템의 상용 화는 맞춤형 인솔 분야에서 부상하고 있다. 과거 인 솔제작은 석고로 발 모형을 뜬 후, 모형에 맞는 인솔 의 높이를 전문가가 결정하여 제작하는 방식이었다. 이러한 수작업 방식은 과정이 복잡하고, 축적된 기술 을 가진 전문가가 필요하며, 많은 제작 시간이 소요 된다. 그러나 $3 \mathrm{D}$ 스캐너와 $3 \mathrm{D}$ 프린터와 같은 $3 \mathrm{D}$ 기 기가 보급되면서 인솔의 제작 과정 단축이 가능하게 되었다. $3 \mathrm{D}$ 스캐너를 사용하면 발의 치수를 프레임 단위로 측정하고 정합하여 정밀한 $3 \mathrm{D}$ 인솔 모델을 생성할 수 있으며, 모델링한 인솔은 3D 프린터를 사 용하며 원하는 소재로 출력할 수 있다(Song et al., 2016). 맞춤형 3D 프린팅 인솔 제조업체인 위브(Wiivv) 는 고객이 스마트 앱을 사용하여 다섯 방향의 발 사진 을 촬영하여 보내면, 사진에서 발 윤곽을 캡처하여 발 아치와 발뒤꿈치에 200개의 포인트를 만들어 맞춤 형 인솔을 모델링하고, $3 \mathrm{D}$ 프린터로 제작하여 10 일 이내에 완제품을 고객에게 발송한다(Benedict, 2017). 피츠인솔(Phits Insoles)의 맞춤형 인솔 제작 시스템인 Phits Expert Workflow에서는 footscan ${ }^{\circledR}$ 시스템을 사 용하여 개인의 동적 보행 특성과 정적인 발 형태 데 이터를 수집하고, 이를 분석하여 디자인한 인솔을 $3 \mathrm{D}$ 프린터로 출력한다(Phits, n.d.b). 피츠인솔은 2016 리 우 올림픽에서 12 명의 선수들에게 고품질의 맞춤형 3D 프린팅 인솔을 제공하였으며(Phits, 2016), 이러한 맞춤형 인솔은 경기력 향상을 원하는 운동선수뿐만 아니라, 족저근막염 및 중족골에 이상이 있거나, 발 부위에 상해를 입은 사람들이 발의 기능을 회복할 수 있도록 도와준다(Phits, n.d.a). 이와 같이 해외의 경우 디자인 개발 단계에서부터 완제품 제조에 이르기까 지 생산의 모든 단계에서 $3 \mathrm{D}$ 프린팅 기술이 활용되 고 있으나, 국내에서는 컨셉 디자인 단계에서 $3 \mathrm{D}$ 프 린터를 사용하는 것이 대부분이다. 국내 제조업의 국 제 경쟁력을 높이기 위해서는 $3 \mathrm{D}$ 스캐닝과 $3 \mathrm{D}$ 프린 팅을 연계한 다양한 $3 \mathrm{D}$ 시스템 콘텐츠를 개발할 필 요가 있다(Oh et al., 2016).

본 연구는 의류산업분야에서 웨어러블(wearable) 제품의 생산에 $3 \mathrm{D}$ 기술 적용의 가능성을 확인하고 의 류제품에 맞는 효율적인 3D 스캐닝, 3D 모델링, 3D 프린팅의 $3 \mathrm{D}$ 시스템 제작 프로세스를 제안하고자 하
였다. 이를 위해 시니어 남성의 $3 \mathrm{D}$ 발 스캔 데이터를 가공하여, 평발의 발 아치에 적합한 인솔의 $3 \mathrm{D}$ 모델 링을 구현하고, 유연한 재질로 $3 \mathrm{D}$ 프린팅하여 착용 가능한 시니어 평발용 인솔을 $3 \mathrm{D}$ 시스템 기반으로 제작하였다. 이와 같은 $3 \mathrm{D}$ 시스템 프로세스는 기능성 인솔 제품뿐 아니라, 다양한 의류패션분야의 제품설 계에서 활용이 가능하다.

\section{Research Process}

본 연구는 $3 \mathrm{D}$ 시스템을 기반으로, 고령화 사회로 인해 급속히 증가하는 시니어 세대를 위한 평발용 인 솔을 제작하였다. 이를 위해 제6차 한국인 인체치수 조사사업에서 수집한 만 60세 이상 69세 이하 남성 189 명의 $3 \mathrm{D}$ 발 스캔 데이터를 가공하여 발바닥의 수 평단면 이미지를 수집한 후, 정상발과 평발 유형을 분류하고, 유형을 대표하는 평균 피험자를 20 명씩 각 각 선정하였다. 선정된 피험자들의 $3 \mathrm{D}$ 발 스캔 형상 에서 수직단면선을 추출한 후 $3 \mathrm{D}$ 좌표를 측정하였으 며, 평균 $3 \mathrm{D}$ 좌표를 각각 연결하여 평발과 정상발의 유형별 발바닥 곡면을 $3 \mathrm{D}$ 모델링하였다. 정상발과 평 발의 발바닥 곡면은 발아치 형상에서 차이가 있었으 며, 평발 유형의 $3 \mathrm{D}$ 모델링 곡면 위에 정상발 유형의 $3 \mathrm{D}$ 모델링 곡면을 중합하여 평발에게 정상적인 발아 치 곡면을 제공하는 $3 \mathrm{D}$ 인솔을 모델링하였다. 인솔 모 델은 신발 안에 부착이 가능하며 착용 시 보행에 불 편함이 없도록 연질의 아크릴계 레진을 사용하여 SLA 방식의 $3 \mathrm{D}$ 프린터로 출력하였다. $3 \mathrm{D}$ 시스템을 이용 하여 시니어 평발용 인솔 제작을 위한 본 연구 프로 세스는〈Fig. 1〉과 같다.

\section{Methods and Results}

\section{Collecting data \& classitying foot types}

\section{1) Collecting $3 D$ foot scan data}

본 연구는 2012년 제6차 한국인 인체치수 조사사 업(SizeKorea)에서 수집한 3D 스캔 자료 중 60 대 (60 69세) 성인 남성의 3D 발 스캔 데이터를 분석하 였다. $3 \mathrm{D}$ 발 형상 스캐닝 및 $3 \mathrm{D}$ 발 치수 자동계측에 사용된 시스템은 (주) K\&I Technology System의 Nex- 


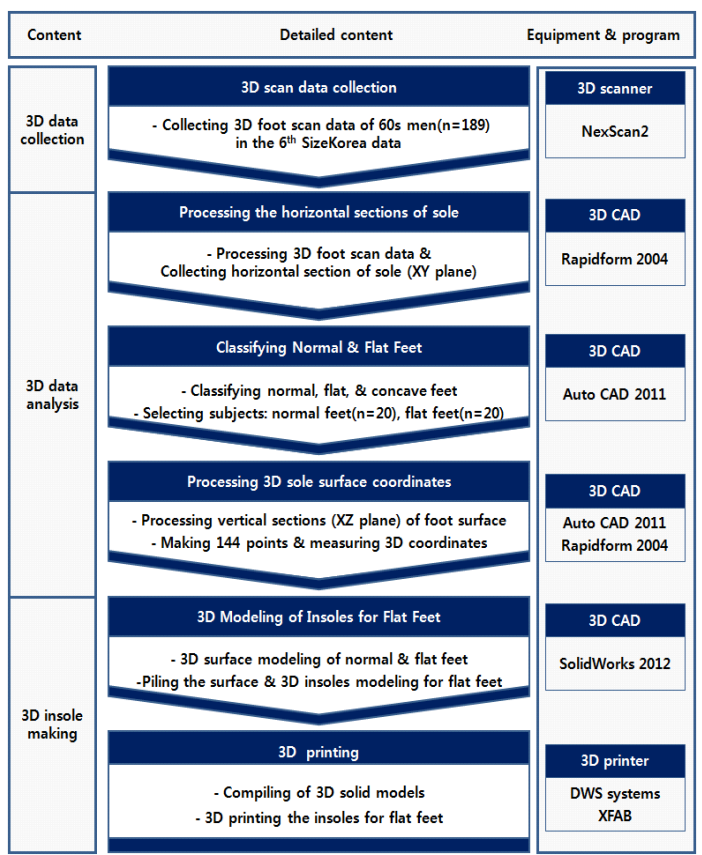

$<$ Fig. 1> Research process

Scan2 기종이었으며, 3D 스캔된 발 형상은 포인트 클 라우드(Point Cloud)로 수집된 후 폴리건(Polygon) 형 태로 저장되었다. K\&I Technology의 자동계측 프로 그램에 의해 총 24 개 항목의 치수가 측정되었으며, 60 대 남성의 $3 \mathrm{D}$ 발 형상 데이터 205 개 중에서, 자동 계측 프로그램에서 측정한 총 24 개의 발 관련 항목에 대해 측정 항목별 결측치가 없고, $3 \mathrm{D}$ 발 형상에 오류 가 없는 189 개의 발 스캔 데이터가 연구 자료로 최종 선정되었다.

\section{2) Processing horizontal sections of $3 D$ foot scan} data

본 연구에서는 $3 \mathrm{D}$ 스캔 데이터를 활용하여 평발 유형 분류가 가능하도록 최적의 발바닥 수평단면도 (Horizontal Section, HS)를 구하는 방법을 고안하였 다. Lee et al.(2014)의 선행 연구를 참고하여, 3D 발 데이터를 바닥면에서부터 $1 \mathrm{~mm}$ 간격으로 슬라이싱 하여 XY평면과 평행한 11 개의 수평단면도를 추출한 후, 정상발, 평발, 오목발의 유형 분류에 최적인 수평 단면도가 관찰되는 발바닥 높이를 확인하였다. 수평 단면도 추출에는 Rapidform 2004 프로그램을 사용 하였으며, 폴리건 형태의 3D 발 데이터(Fig. 2(a))를 바닥면(XY평면)에서부터 $10 \mathrm{~mm}$ 높이까지 $1 \mathrm{~mm}$ 간 격으로 슬라이싱하여 폴리라인(Polyline) 형태의 발 바닥 수평단면도(Fig. 2(b))를 가공하였다. 총 HS1부 터 HS11까지 11 개의 발바닥 수평단면도가 제작되었 다(Fig. 2(c)).

발바닥 수평단면도를 분석한 결과, 선행 연구(Kim, 2001; Kim, 2003)의 발 지문 분석에서 기준으로 사용 한 7 개의 기준점과 3 개의 기준선이 모두 관찰된 수평 선의 높이는 바닥면에서 $2 \mathrm{~mm}$ 높이의 수평단면도 (HS3)였다. 발아치 유형에 필요한 기준점을 모두 표 시하면서 발아치의 높낮이를 시각적으로 표현하기 위해, 최종적으로 바닥면을 지나는 수평단면도(HS1), 바닥에서 $1 \mathrm{~mm}$ 떨어진 수평단면도(HS2), 바닥에서 $2 \mathrm{~mm}$ 떨어진 수평단면도(HS3)의 3 단계로 이루어진 등고선을 발바닥 유형 분석을 위한 데이터로 사용하 였다.

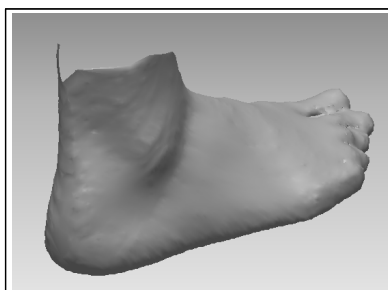

(a) 3D foot scan data

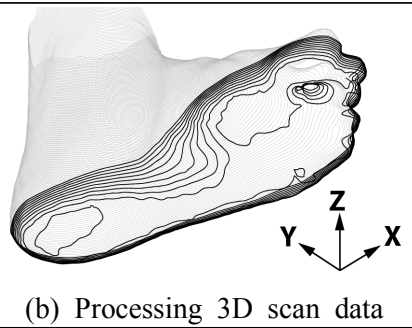

(b) Processing 3D scan data

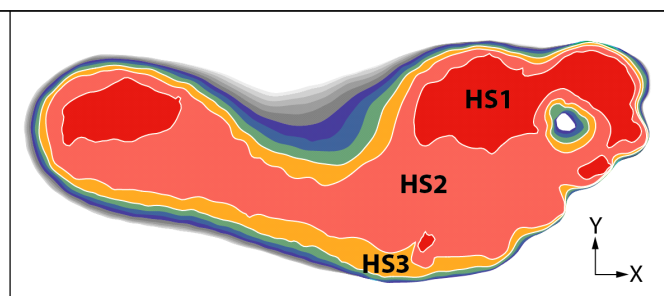

(c) Horizontal sections of sole

note) : HS1, Horizontal section of sole in bottom line HS2, Horizontal section of sole in $1 \mathrm{~mm}$ from the bottom HS3, Horizontal section of sole in $2 \mathrm{~mm}$ from the bottom HS4, Horizontal section of sole in $3 \mathrm{~mm}$ from the bottom HS5, Horizontal section of sole in $4 \mathrm{~mm}$ from the bottom HS6, Horizontal section of sole in $5 \mathrm{~mm}$ from the bottom

: HS7, Horizontal section of sole in $6 \mathrm{~mm}$ from the bottom : HS8, Horizontal section of sole in $7 \mathrm{~mm}$ from the bottom : HS9, Horizontal section of sole in $8 \mathrm{~mm}$ from the bottom : HS10, Horizontal section of sole in $9 \mathrm{~mm}$ from the bottom HS11, Horizontal section of sole in $10 \mathrm{~mm}$ from the bottom

<Fig. 2> Horizontal sections of sole for foot types 
3) Classifying foot arch types; normal, flat, and concave foot

〈Fig. 2〉에서 추출한 등고선 형태의 수평단면도로 부터 발아치 유형을 정상발, 평발, 오목발로 분류하였 다. 바닥에서 $2 \mathrm{~mm}$ 떨어진 발바닥 수평단면도(HS3) 에서 발볼 내측 바깥 점(1)과 발뒤꿈치 내측 바깥 점 (2)을 지나는 접선(A)과, 발볼 외측 바깥 점(3)과 발뒤 꿈치 외측 바깥 점(4)을 지나는 접선(B)을 그리고, 두 선이 만나는 점(6)을 표시한 후, 이 점과 두 번째 발 가락의 중심(5)을 연결한 직선(C)을 그렸다. 발바닥 수평단면도에 그린 중심선 $(\mathrm{C})$ 보다 바깥쪽에 발아치 (7)가 있는 경우, 정상발(Fig. 3(a)), 중심선(C)보다 안 쪽에 발아치(7)가 있는 경우는 평발(Fig. 3(b)), 발바 닥 수평단면도에 발아치(7)가 나타나지 않는 경우는 오목발로 분류하였다(Fig. 3(c)). 60대 남성 $(n=189)$ 의 $3 \mathrm{D}$ 발 스캔 자료로부터 추출한 발바닥 수평단면도를 분석한 결과, 정상발 139명(73.5\%), 평발 50명(26.5\%) 으로 분류되었으며, 오목발 유형은 분류되지 않았다.

\section{4) Selecting average subjects by foot types}

발 유형별 평균 발바닥 곡면을 구하기 위해, 60 대 남성의 정상발과 평발을 대표할 수 있는 피험자들을 각각 20 명씩 선정하였다. 발아치 유형 분류에서 정상 발로 분류된 139 명과 평발로 분류된 50 명의 자동계 측 치수 중에서, 발직선길이(1), 발너비(5), 발등높
이(8), 발등둘레(13)의 치수가 한국인 인체치수 조사 사업의 60 대 남성 전체 $(n=189)$ 평균값에 가까운 대표 피험자를 각각 20 명씩 선정하였다. 선정된 정상발 대 표 피험자 $(n=20)$ 와 평발 대표 피험자 $(n=20)$ 의 발 치 수는 〈Table 1)과 같았으며, 60 대 남성 평균 발 치수와 통계적으로 유의한 차이는 없었다. 선정된 발 유형별 대표 피험자들의 전체 평균은 발직선 길이 $243.46 \mathrm{~mm}$, 볼둘레 $251.74 \mathrm{~mm}$ 로, 기술표준원의 신발의 치수체계 (KS M 6681 : 2007)에 따르면 245EEE에 해당하였다 (Korean Agency for Technology and Standards, 2012).

\section{Analysis of sole surface}

\section{1) Measuring $3 D$ coordinates of sole surface}

발 유형별 대표 피험자의 $3 \mathrm{D}$ 발 데이터에서 정량 적 분석이 가능한 $3 \mathrm{D}$ 좌표 데이터를 얻기 위해, 발바 닥 곡면을 이루는 주요 변곡점을 따라 9 개의 수직 단 면 기준선을 설정하고, 각각의 기준선 위에 등 간격 으로 기준점을 총 144 개 만든 후, 각 포인트의 $3 \mathrm{D}$ 좌 표 값을 측정하였다. $3 \mathrm{D}$ 발 데이터의 수직 단면선 형 성과 발바닥 곡면 기준선 및 기준점 선정과 측정 방 법은 다음과 같다(Fig. 4).

Step. 1. 수직단면선 슬라이싱: 3D 발 데이터 위에 $\mathrm{XZ}$ 평면과 평행한 참조평면을 $1 \mathrm{~mm}$ 간격으로 형 성한 후, $3 \mathrm{D}$ 폴리건 데이터와 참조평면이 만나

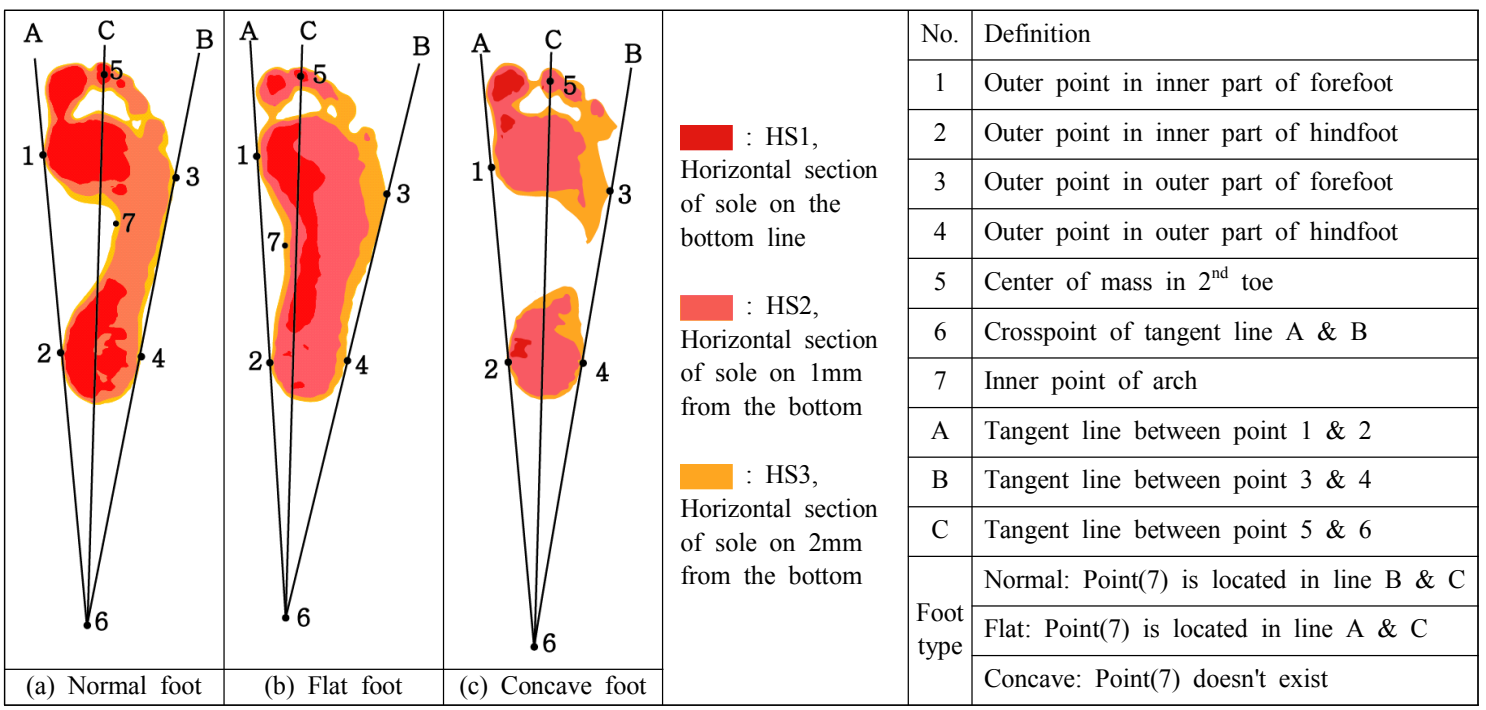

<Fig. 3> Classification of foot types using horizontal sections of sole 


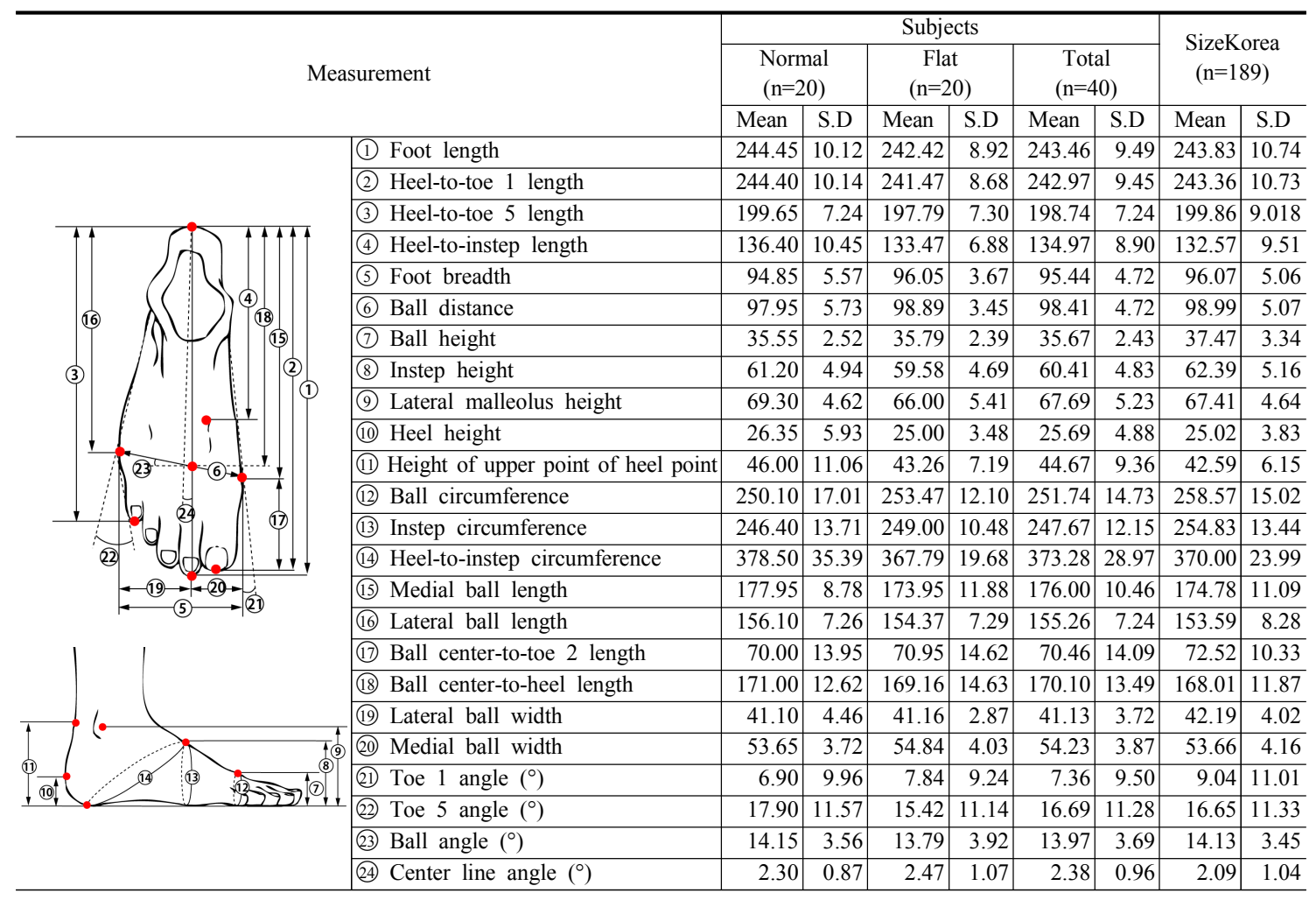

는 경계선을 따라 형성된 폴리라인을 슬라이싱 하여 수직단면선을 추출하였다. 슬라이싱 과정은 Rapidform 2004를 사용하였다.

Step.2. 발바닥 외곽선(SL) 설정: $1 \mathrm{~mm}$ 간격으로 형 성된 수직단면선 위에 발바닥 외곽선(Sole line, $\mathrm{SL})$ 을 그렸다. 발바닥 외곽선(SL)은 발가락 두께 의 이등분점(1)과 발뒤꿈치점(2)을 지나며, 발바 닥을 XY평면 방향에서 내려다보았을 때 중족부 외측 가장 바깥쪽점(3)과 내측 가장 안쪽점(4)을 지나는 점을 연결한 스플라인(Spline) 곡선으로 제작하였다.

Step.3. 발바닥 곡면(Sole) 분리: 가공한 수직단면 선을 $\mathrm{SL}$ 을 따라 두 부분(upper \& sole)으로 분리 하고, 인솔 제작에 필요한 발바닥 곡면 데이터는 아래 부분의 수직단면선을 사용하였다.

Step.4. 발바닥 기준선 설정: 발바닥 곡면의 변곡점 을 포함하는 9 개의 단면선을 설정하고, 이를 발 바닥 수직기준선(Vertical Section, VS)으로 명명 하였다. VS1: 발바닥 내측에서 가장 바깥쪽 선,
$\mathrm{VS} 2: \mathrm{SL}$ 의 내측점을 지나는 선, VS3: VS2과 VS4 의 중간선, VS4: 첫째발가락 중심점을 지나는 선, VS5: 둘째발가락 중심점을 지나는 선, VS6: 셋째발가락 중심점을 지나는 선, VS7: 넷째발가 락 중심점을 지나는 선, VS8: 다섯째발가락 중심 점을 지나는 선, VS9: 발바닥 외측에서 가장 바 깥쪽 선을 각각 기준선으로 설정하였다.

Step.5. 발바닥 3D 좌표데이터 설정: 9 개의 발바닥 수직기준선(VS1 VS9) 위에 등간격의 기준점을 형성하였다. 각 수직기준선의 기준점은 좌표데이 터의 손실을 최소화하면서도 계측의 용이성을 위해 선분 길이를 고려하여 등분점으로 설정하 였다. 폴리라인의 길이가 긴 VS3, VS4, VS5, VS6, $\mathrm{VS} 7$ 은 20 등분하여 총 21 개의 등간격 포인트를, 폴리라인의 길이가 짧은 VS1과 VS9은 기준선을 5 등분하여 총 6 개의 등간격 포인트를 형성하였 다. 또한 폴리라인의 길이가 중간인 VS2은 기준 선을 15 등분하여 총 16 개의 포인트를, VS8은 10 등분하여 총 11 개의 등간격 포인트를 형성하였 

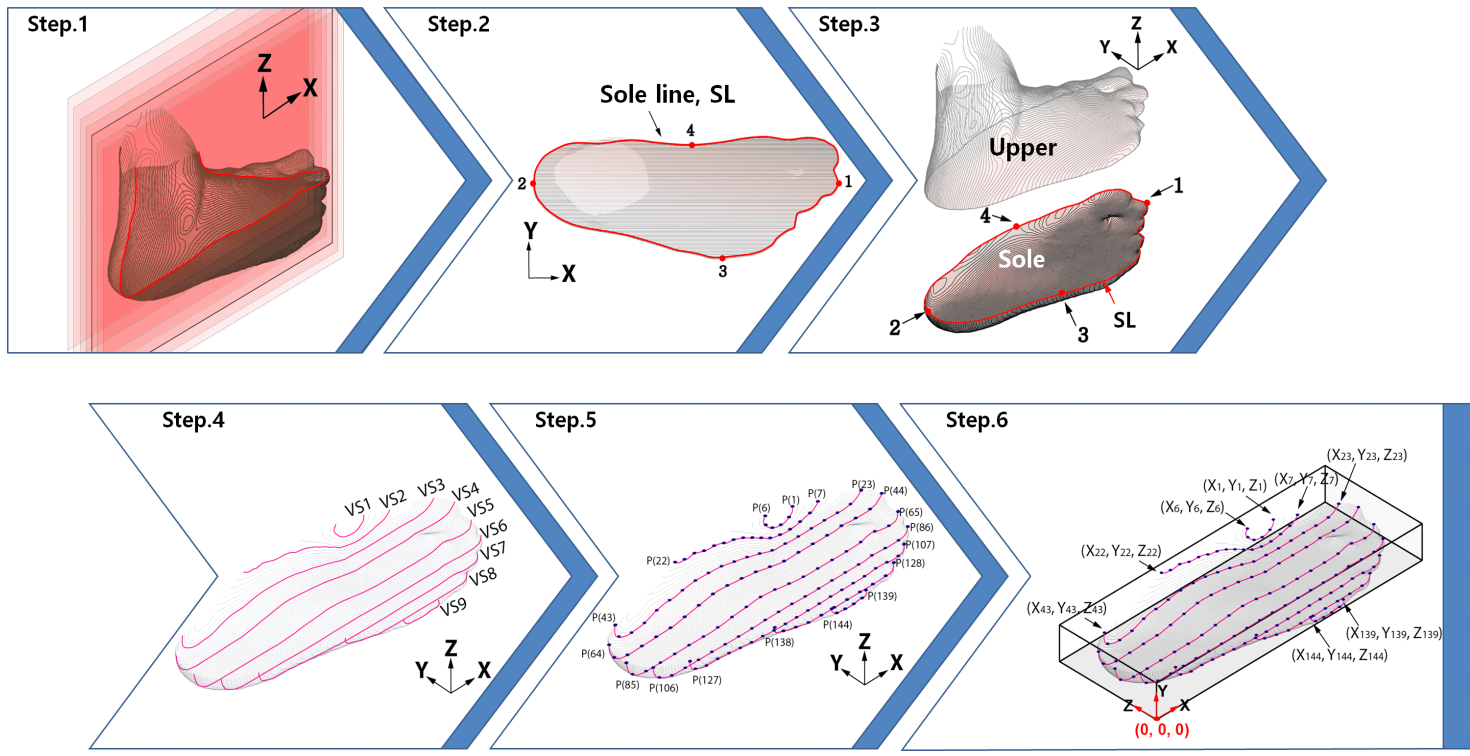

<Fig. 4> Processing 3D foot scan data and measuring 3D coordinates of sole

다. 포인트 형성에는 AutoCAD 2011 프로그램이 사용되었으며 총 144 개의 포인트가 형성되었으 며, 이 점들을 발바닥 $3 \mathrm{D}$ 좌표데이터로 설정하 였다.

Step.6. 발바닥 3D 좌표데이터 측정: 정상발 스캔 데이터 $(n=20)$ 와 평발 스캔데이터 $(n=20)$ 의 발바닥 에 형성된 144 개 좌표점의 $3 \mathrm{D}$ 좌표 값 $\left(\mathrm{X}_{1}, \mathrm{Y}_{1}\right.$, $\left.\left.\mathrm{Z}_{1}\right), \ldots,\left(\mathrm{X}_{144}, \mathrm{Y}_{144}, \mathrm{Z}_{144}\right)\right)$ 을 각각 측정하였다.

\section{2) Analyzing 3D coordinates of sole surface by}

\section{foot types}

144 개 기준점의 $3 \mathrm{D}$ 좌표를 측정하고, 유형별 평균 값을 구하여 정상발과 평발 발바닥 곡면의 경향을 전 족부, 중족부, 후족부로 나누어 분석하였다. $3 \mathrm{D}$ 좌표 데이터에서 $\mathrm{X}$ 좌표는 발바닥의 길이, $\mathrm{Y}$ 좌표는 발바닥 의 너비, Z좌표는 발아치의 높이 경향을 나타내며, 이 중 평발용 인솔 제작에 중요한 요인인 발바닥 아치의 높이를 나타내는 것은 $\mathrm{Z}$ 방향의 좌표 값이다. 각 라인 별 $3 \mathrm{D}$ 좌표데이터 분석 결과는 〈Table 2〉 〈Table 4〉 와 같다.

발바닥 내측에 위치한 수직기준선 VS1, VS2, VS3의 평균 좌표 값을 살펴보면, $\mathrm{VS} 2$ 에서는 $\mathrm{X}$ 좌표 $(\mathrm{P}(7)$ $\mathrm{P}(14), \mathrm{P}(20) \sim \mathrm{P}(22))$ 와 $\mathrm{Z}$ 좌표 $(\mathrm{P}(17) \sim \mathrm{P}(22))$ 에서 정상 발과 평발의 좌표 값이 $3 \mathrm{~mm}$ 이상 차이가 나타났으
며, $\mathrm{VS} 3$ 에서는 $\mathrm{X}$ 좌표 $((\mathrm{P}(23) \sim \mathrm{P}(26))$ 와 $\mathrm{Z}$ 좌표 $((\mathrm{P}(33)$ $\mathrm{P}(38))$ 에서 발 유형 사이에 $3 \mathrm{~mm}$ 이상 차이를 보였다. 특히 $\mathrm{VS} 1 \sim \mathrm{VS} 9$ 의 모든 기준선들 중 $\mathrm{Z}$ 좌표 값의 차이 가 이 구간에서 가장 크게 나타나, 평발과 정상발의 편평도 차이가 가장 큰 구간이 발바닥 내측선 VS3임 을 알 수 있었다(Table 2).

발바닥 중앙부의 수직기준선 VS4, VS5, VS6에서 평발과 정상발의 평균 좌표 값이 $3 \mathrm{~mm}$ 이상 차이를 보 인 구간은 VS4의 $\mathrm{X}$ 좌표 $(\mathrm{P}(44) \sim \mathrm{P}(46))$ 와 $\mathrm{Z}$ 좌표 $(\mathrm{P}(53) \sim$ $\mathrm{P}(57))$ 였으며, 특히 VS4의 중족부 구간(P(53) P(57)) 의 Z좌표 값 차이는 최대 $5.185 \mathrm{~cm}$ 로 나타나, 발 유형 에 따른 발아치의 높이 차이가 큰 부위임을 알 수 있 었다(Table 3).

발바닥 외측부의 수직기준선 VS7, VS8, VS9에서 $\mathrm{Z}$ 좌표 값이 $3 \mathrm{~mm}$ 이상 차이를 보이는 구간은 없어, 평발과 정상발의 아치 차이는 없는 것으로 나타났다. 다만, $\mathrm{VS} 8$ 의 전족부, 중족부와 $\mathrm{VS} 9$ 의 중족부의 X좌 표 값에 차이가 있어 정상발이 평발보다 앞쪽에 위치 하는 것으로 나타났다(Table 4).

유형별 발바닥 곡면의 $3 \mathrm{D}$ 좌표데이터를 종합하면, $\mathrm{X}$ 좌표에서 $3 \mathrm{~mm}$ 이상 좌표 값의 차이가 나타난 수직 기준선은 $\mathrm{VS} 2, \mathrm{VS} 3, \mathrm{VS} 4, \mathrm{VS} 8, \mathrm{VS} 9$ 으로, 발바닥의 외측 부위와 내측 부위에서 정상발이 평발보다 크며 발가락과 전족부의 길이가 정상발이 평발보다 길었 
<Table 2> Measurements of 3D coordinates: VS1, VS2, VS3

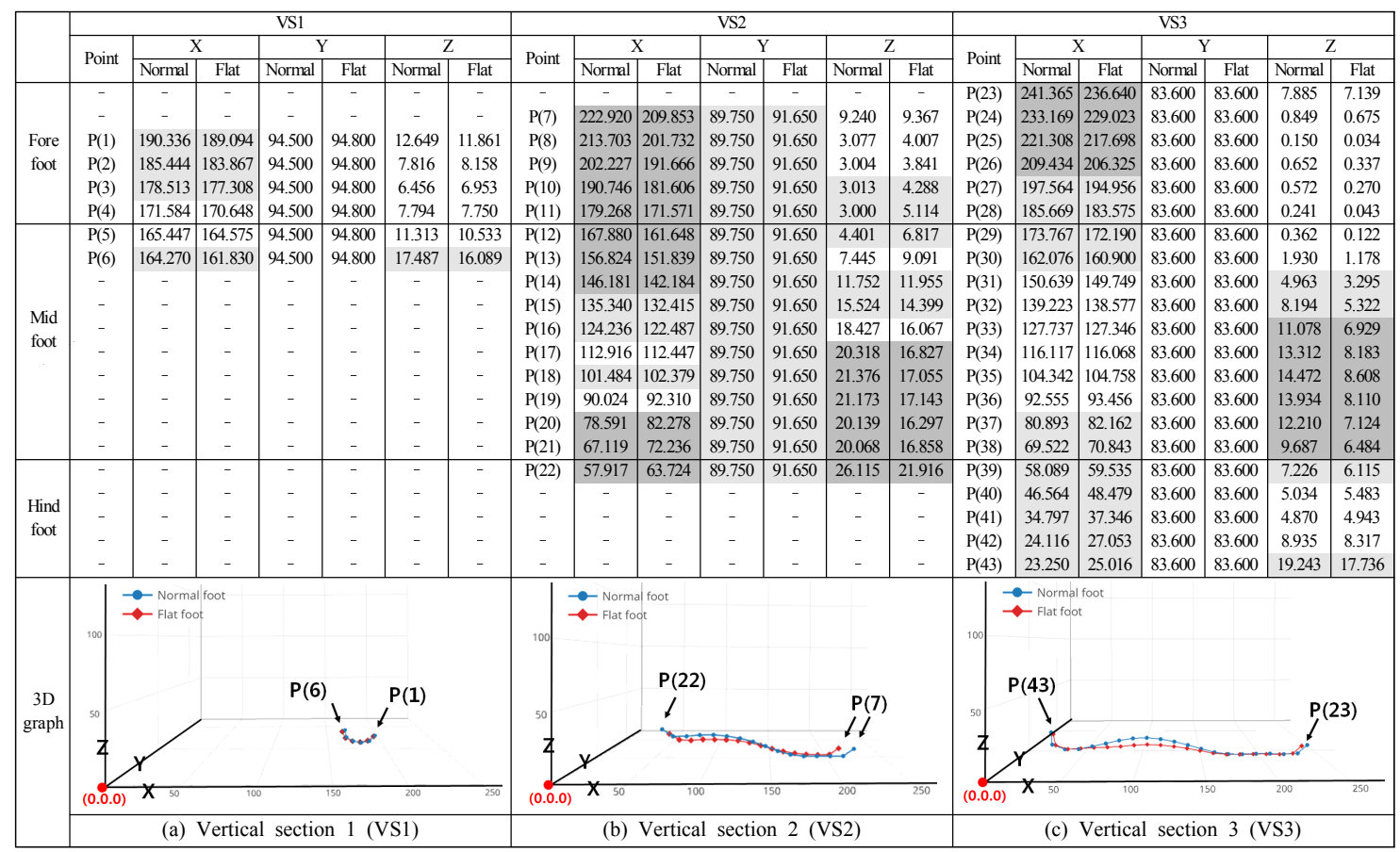

Note) : The difference is more than $3 \mathrm{~mm}$ between flat and normal

: The difference is within 1 3 mm between flat and normal

<Table 3> Measurements of 3D coordinates: VS4, VS5, VS6

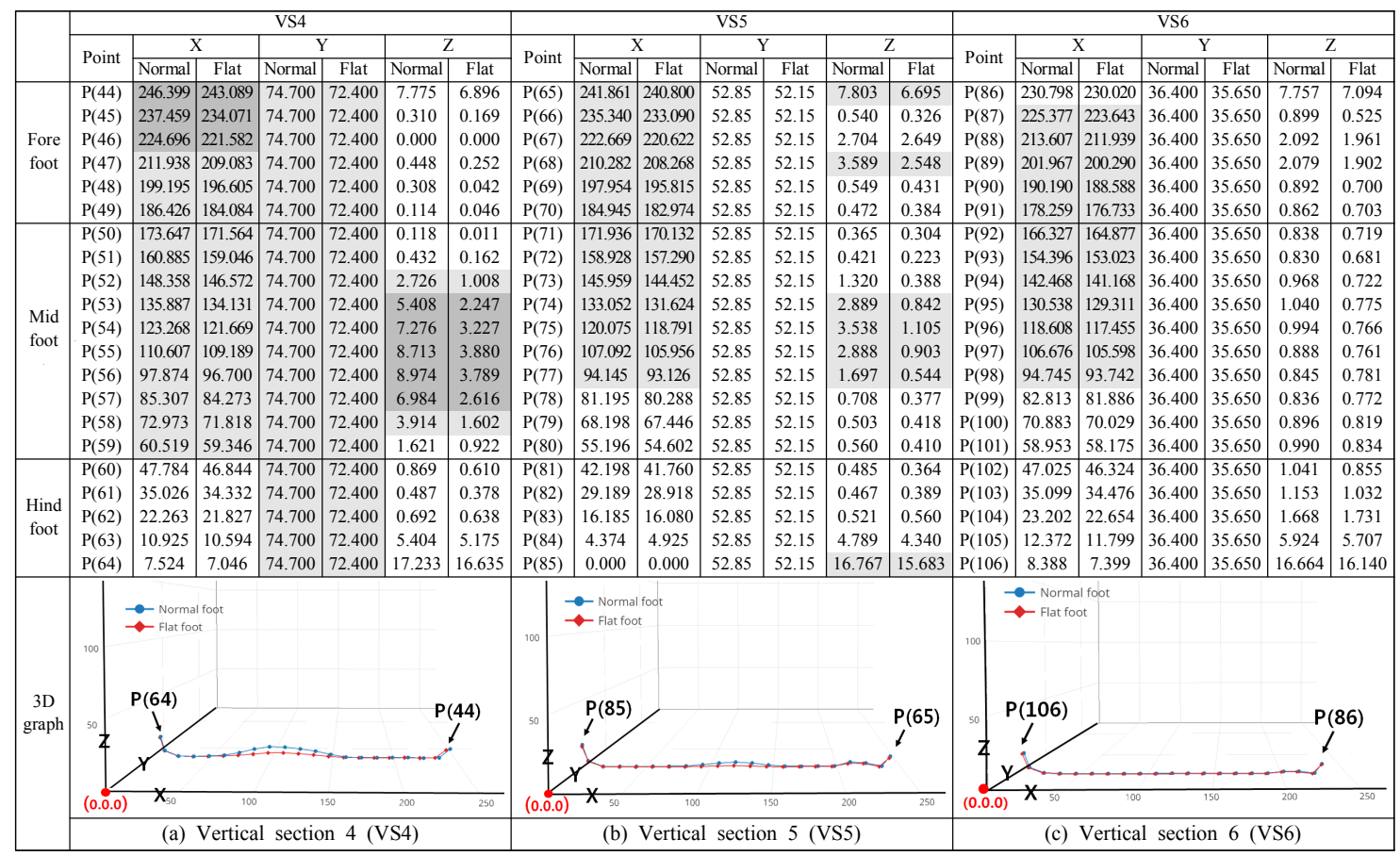

Note) $\quad:$ The difference is more than $3 \mathrm{~mm}$ between flat and normal

: The difference is within $1 \sim 3 \mathrm{~mm}$ between flat and normal 
다. $\mathrm{Y}$ 좌표에서 $3 \mathrm{~mm}$ 이상 좌표 값의 차이가 나타난 수직기준선은 없는 것으로 나타나, 평발과 정상발의 발 너비의 차이는 많지 않음을 확인할 수 있었다. 발 바닥 아치 높이 차이를 설명하는 Z좌표의 경우, $3 \mathrm{~mm}$ 이상 좌표 값의 차이가 나타난 수직기준선은 $\mathrm{VS} 2$, $\mathrm{VS} 3, \mathrm{VS} 4$ 였다. 정상발과 평발의 아치 높이에 따른 위치 차이는 VS2에서 시작되어 VS3의 중족부에서 최 댓값 $(5.864 \mathrm{~mm})$ 를 나타냈으며, VS4까지 이러한 경향 이 유지되었다. VS5 이후로는 Z좌표 값의 차이가 크 지 않아 평발과 정상발의 고유한 발바닥 아치 공간은 발 내측선에서부터 첫째발가락선까지인 발바닥 중족 부 안쪽 구간에 위치하고 있음을 알 수 있다.

\section{3D modeling}

\section{1) $3 D$ modeling sole surfaces by foot types}

발바닥 $3 \mathrm{D}$ 좌표데이터로부터 정상발과 평발의 발 바닥 곡면을 $3 \mathrm{D}$ 모델링하였다. 모델링 과정은 다음과 같다(Fig. 5).
Step.1. 발바닥 곡면의 스플라인 설정:〈Table 2〉 〈Table 4〉에서 측정한 144 개 기준점을 AutoCAD 2011 프로그램의 3D 평면에 위치시킨 후, $\mathrm{Y}$ 좌표 값이 같은 점들을 연결하여 스플라인 곡선을 만 들었다. 총 9 개의 수직기준선이 스플라인 곡선 (VS1 VS9)으로 설정되었다.

Step.2. 발바닥 로프트 곡면 모델링: Step.1에서 설 정된 수직기준선 VS1 VS9을 3D 로프트 곡면 모 델링의 스케치선(Sketch line)으로 사용하여 발바 닥의 곡면을 $3 \mathrm{D}$ 모델링하였다. $3 \mathrm{D}$ 곡면 모델링 에는 Solidworks 2012가 사용되었다.

Step.3. 발바닥 곡면 3D 모델링 완성: 정상발과 평 발 발바닥을 $3 \mathrm{D}$ 곡면으로 최종 완성하였으며, 전면, 측면, 등각뷰는 〈Fig. 5〉(Step.3)와 같다.

\section{2) $3 D$ modeling the insoles for flat feet}

발바닥의 아치가 낮아 지면과 닿는 발바닥 면적이 많은 평발의 구조적 문제점을 개선하기 위해서는, 신 발과 발바닥이 맞닿는 부분에 적절한 아치를 제공할

$<$ Table 4> Measurements of 3D coordinates: VS7, VS8, VS9

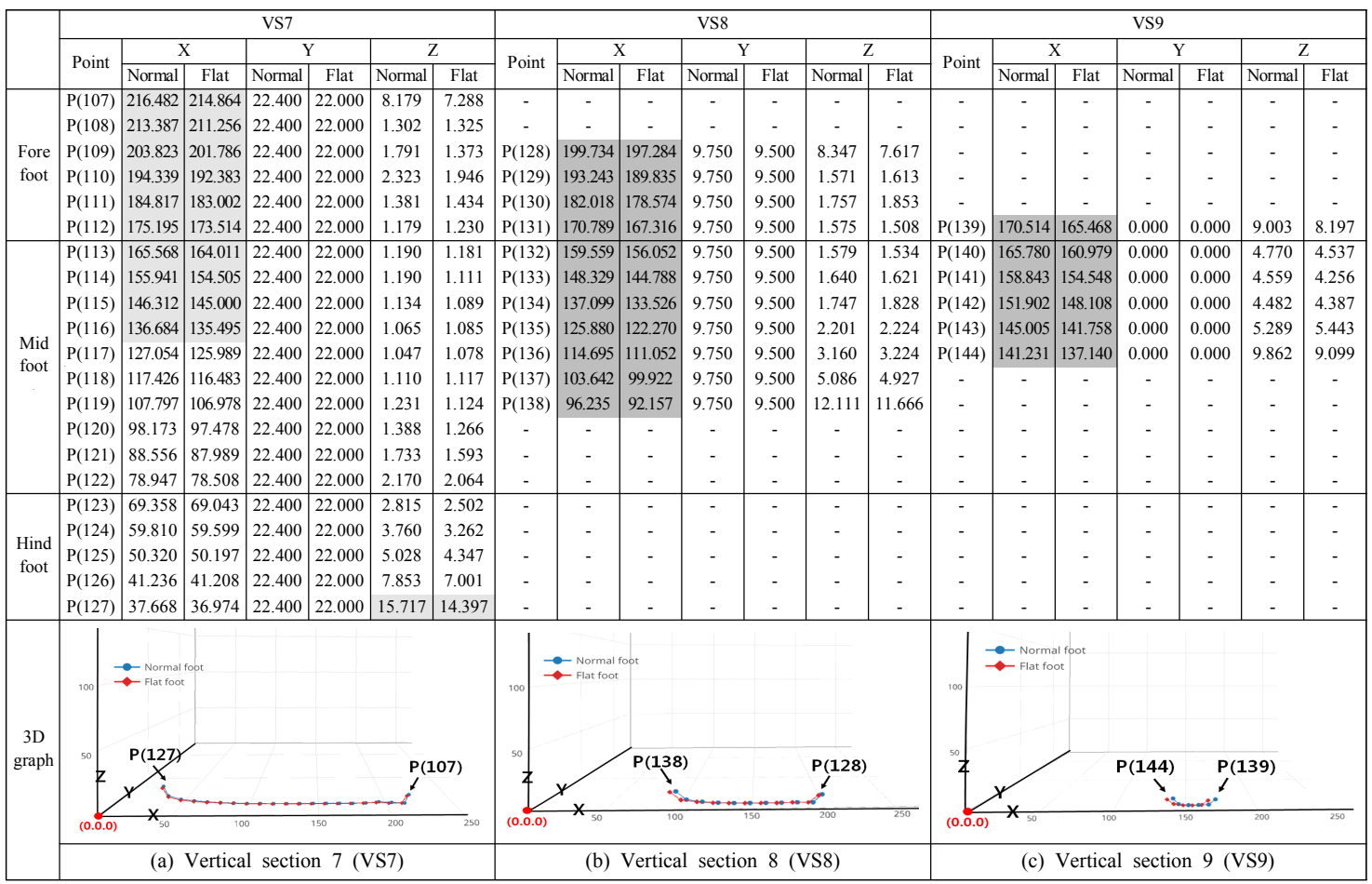

Note)

The difference is more than $3 \mathrm{~mm}$ between flat and normal

: The difference is within $1 \sim 3 \mathrm{~mm}$ between flat and normal 

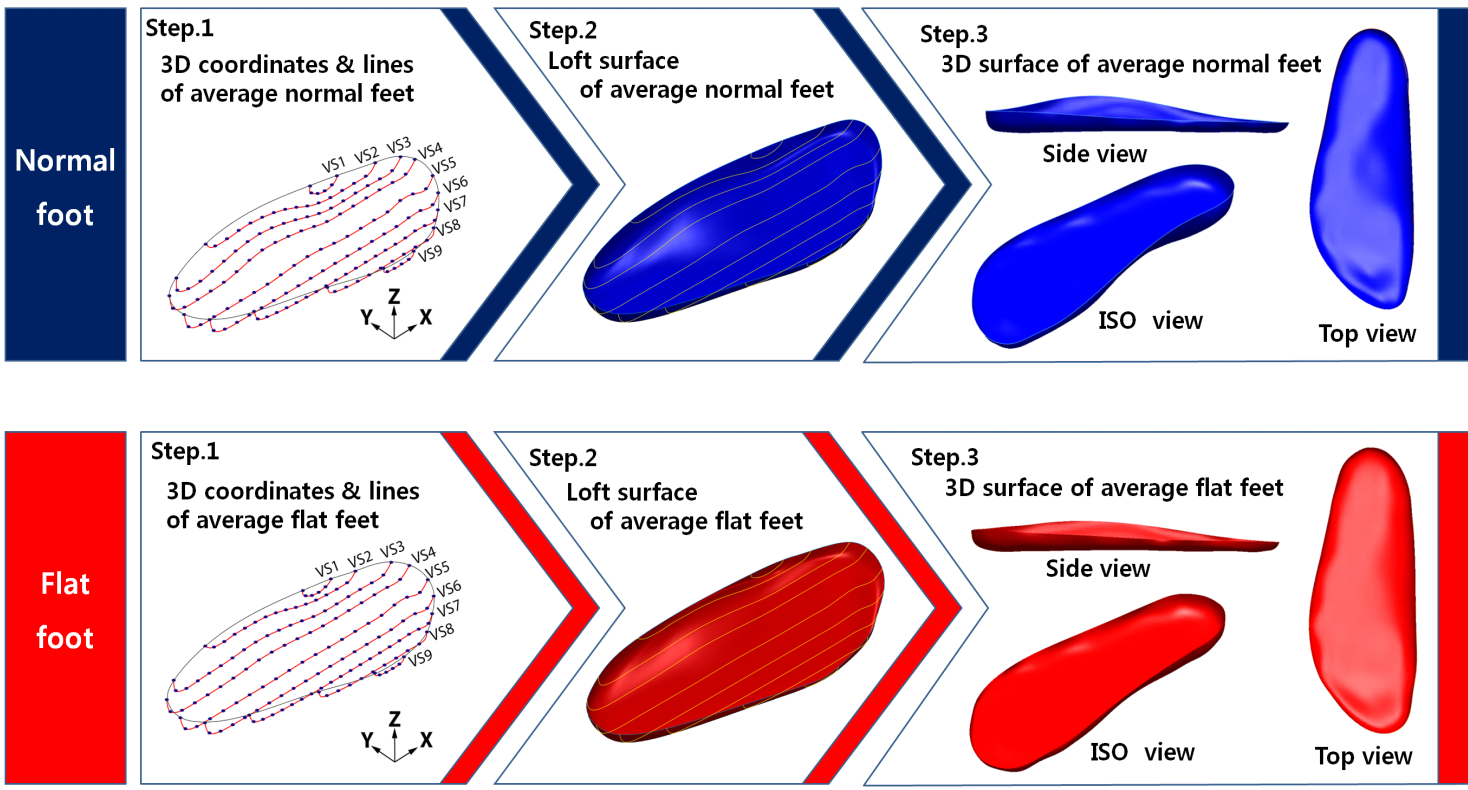

Step.3

3D surface of average flat feet

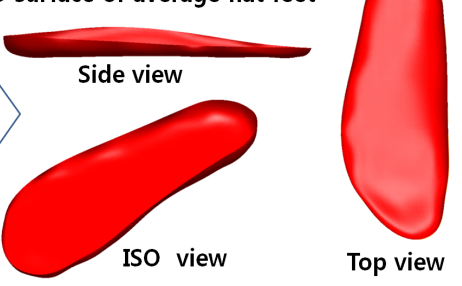

<Fig. 5> 3D modeling soles for normal feet and flat feet

수 있게 보형물을 삽입하여 발의 편평도를 정상발의 수준으로 높여 주어야 한다. 이를 위해〈Fig. 6〉(Step.1) 에서 제작한 평발 발바닥 곡면과 정상발 발바닥 곡면 을 중합하여, 편평한 평발의 발바닥 곡면을 정상 곡 률을 가진 발바닥 곡면으로 만들고자 하였다(Fig. 6).
Step.1. 발바닥 곡면의 중합 : 〈Fig. 5〉(Step.3)에서 제작한 평발의 발바닥 곡면과 정상발의 발바닥 곡 면을 원점 $(0,0,0)$ 을 기준으로 중합하였다. 중합 결과, 평발과 정상발의 발바닥 내측 아치의 곡률 차이로 인해 나타나는 발바닥의 굴곡이 중합모
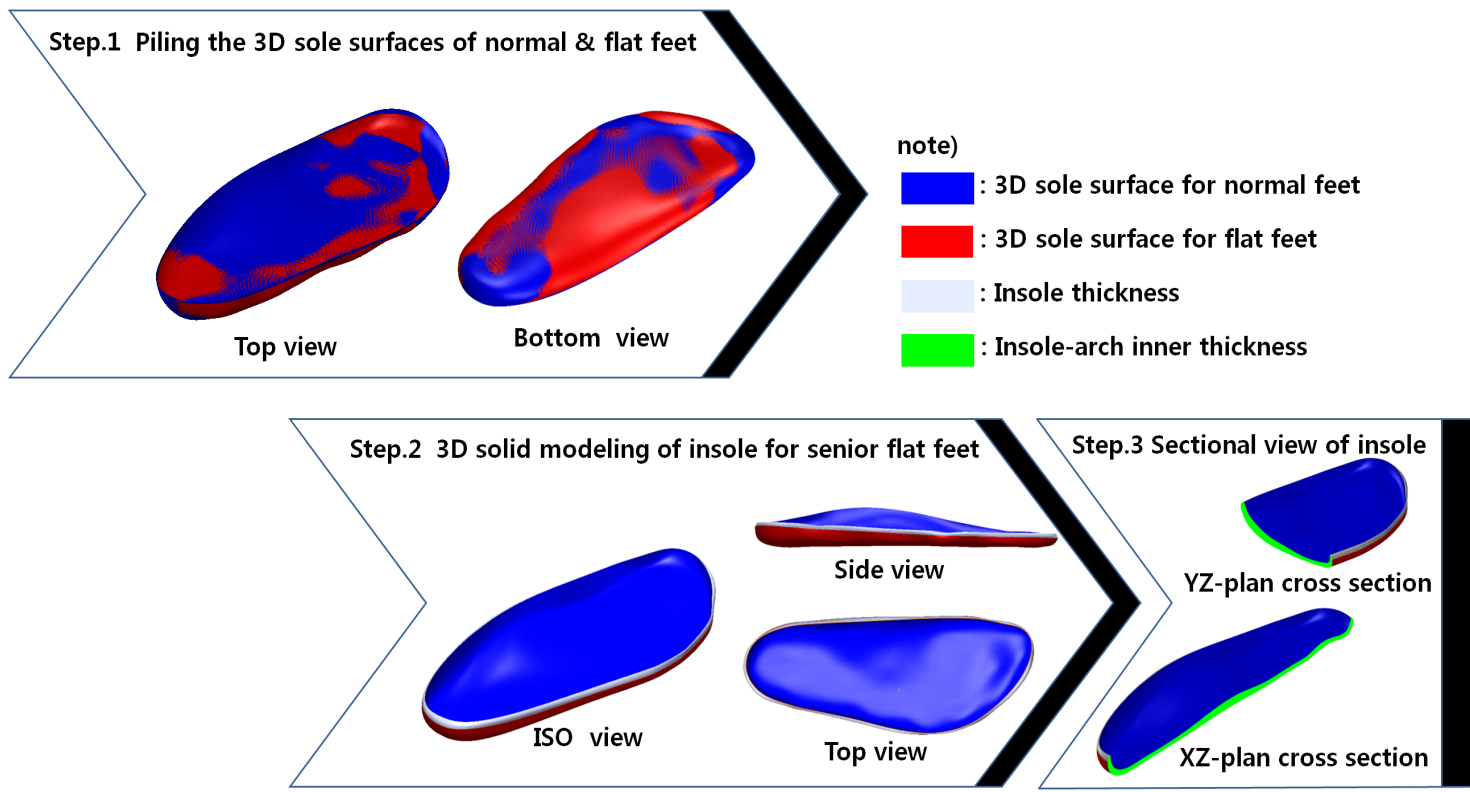

<Fig. 6> 3D modeling soles for normal feet and flat feet 
형에 반영되어 입체적인 커브 곡면 형태를 보였다.

Step.2. 인솔의 3D 모델링 : 인솔 착용 시 착화감을 높이고 보행 시 발에 가해지는 무게를 흡수할 수 있도록, 평발과 정상발이 맞닿은 중합 곡면의 접 합면에 $5 \mathrm{~mm}$ 의 쿠션 두께를 추가하였다. $5 \mathrm{~mm}$ 의 쿠션을 더한 후 $3 \mathrm{D}$ 인솔의 두께는 평발과 정상 발의 $\mathrm{Z}$ 좌표 값 차이가 가장 컸던 $\mathrm{VS} 3$ 의 중족부 구간(P(35), 5.864mm)에서 $10.9 \mathrm{~mm}$ 로 가장 두꺼 웠으며, 정상발이 평발보다 발아치 높이가 낮아 평발과 정상발의 Z좌표 값의 차이가 가장 작았 던 $\mathrm{VS} 2$ 의 중족부 앞쪽 $(\mathrm{P}(12),-2.416 \mathrm{~mm})$ 에서 2.8 $\mathrm{mm}$ 로 가장 얇았다. Solidworks 2012 프로그램 으로 인솔의 로프트 피쳐를 $3 \mathrm{D}$ 모델링하였다. 피쳐 생성 시 밑면의 프로파일에는 평발의 로프 트 곡면이, 윗면의 프로파일에는 정상발의 로프 트 곡면이 사용되었다.

Step.3. 평발용 인솔의 완성: 최종 완성된 평발용 인솔을 $\mathrm{YZ}, \mathrm{XZ}$ 방향으로 절단해 보면, 평발용 인솔이 신발과 닿는 밑면은 평발 발바닥 곡면의 편평도를 반영하여 굴곡이 없는 상태이고, 착용 자의 발이 닿는 윗면은 정상발의 발바닥 곡면을 반영하여 활처럼 휘어진 형태로 설계되었다.

\section{3D printing the insoles for flat feet}

시니어 평발용 인솔의 $3 \mathrm{D}$ 프린팅에는 DWS System의 XFAB 3D 프린터가 사용되었다. XFAB 프린 터는 빛에 반응하는 액체에 자외선 레이저를 쏘아 급 속 경화시켜 한 층씩 얇은 막을 형성함으로써 모형을 출력하는 SLA(Stereo Lithography Apparatus) 방식이 다. $\mathrm{SLA}$ 방식의 $3 \mathrm{D}$ 프린터는 고가이나, 다양한 재료 를 사용하여 정밀한 해상도의 출력이 가능하다. 인솔 의 $3 \mathrm{D}$ 프린팅 사출재료로는 발바닥 면에 가해지는
충격을 충분히 완화시킬 수 있도록, 유연한 고무재질 의 질감을 구현한 연성 아크릴계 레진(DWS System 의 Rubber-like: FLEXA692) 소재를 선정하였다.

하나의 덩어리 형태로 구성된 $3 \mathrm{D}$ 솔리드 모형을 $3 \mathrm{D}$ 프린터로 한 층씩 출력하기 위해서는, $3 \mathrm{D}$ 모델링 형상을 얇은 층 형태로 슬라이싱 변환해야 한다. $3 \mathrm{D}$ $\mathrm{CAD}$ 에서 모델링 후 $\mathrm{STL}$ 파일로 저장된 시니어 평발 용 인솔의 $3 \mathrm{D}$ 솔리드 모델은 $3 \mathrm{D}$ 프린터용 컴파일 프 로그램인 DWS System의 Nauta+ ver1.2.0을 사용하 여 얇은 슬라이싱 조각으로 분리되었다. 컴파일링된 $3 \mathrm{D}$ 모형은 $3 \mathrm{D}$ 프린터로 한 층씩 출력되었다. 본 연 구에서 사용한 XFAB $3 \mathrm{D}$ 프린터로 한 번에 출력 가 능한 모델의 크기는 $180 \times 180 \mathrm{~mm}$ 이었다. 제작한 평발 용 인솔의 $3 \mathrm{D}$ 모델 크기는 $245 \times 100 \mathrm{~mm}$ 이었기 때문 에 XFAB 프린터로는 한 번에 출력하는 것이 불가능 하였다. 따라서 제한된 플랫폼 크기에 맞추기 위해 인솔을 앞부분과 뒷부분으로 나누어 분할 출력하였 다. $3 \mathrm{D}$ 프린터로 모델을 출력하는데 소요된 시간은 총 8 9시간이었다(Fig. 7).

출력된 $3 \mathrm{D}$ 인솔의 후처리 작업을 진행하였다. 출 력 후 남아 있는 여분의 레진을 제거하기 위하여 알코 올에 담근 후 파우더를 뿌려서 표면의 끈적임을 제거 하였다. 분할 출력된 인솔은 출력 시 사용한 아크릴계 레진을 녹여 접착한 후, 접착 면을 정리하여 최종 완성 하였다. 후처리 단계는 총 6시간 정도가 소요되었다.

완성된 평발용 인솔은 〈Fig. 8〉과 같다. 고무재질과 유사한 물성을 지닌 검정색 아크릴계 레진을 사용하 여 착용 시 자연스럽게 발바닥 부분이 휘어졌다가 다 시 원래 상태로 회복될 수 있는 굽힘력과 회복력을 지니고 있다. 발바닥 곡면이 반영되었으며, 발바닥에 서 측면으로 올라오는 곡선을 포함한 인솔로 제작되 었다.

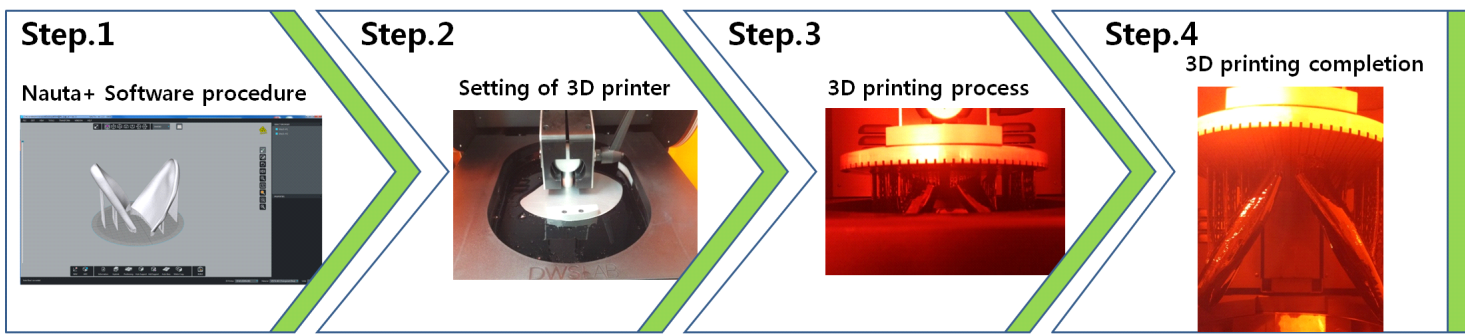

<Fig. 7> 3D printing process of the insoles for flat feet 


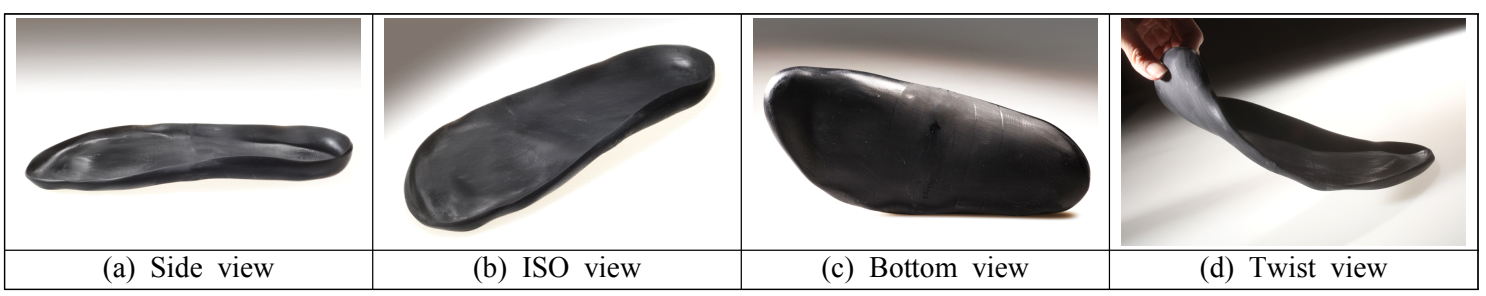

$<$ Fig. 8> 3D printed insoles for flat feet

\section{Conclusion}

본 연구는 제조업에 새로운 패러다임을 제시하고 있는 3D 프린터를 활용하여 평발을 위한 인솔을 제작 하였다. $3 \mathrm{D}$ 스캐너에서 수집된 $3 \mathrm{D}$ 데이터를 가공하고, $3 \mathrm{D} \mathrm{CAD}$ 프로그램을 활용하여 $3 \mathrm{D}$ 모델링을 진행하 고, 제작된 모델을 $3 \mathrm{D}$ 프린터로 제작하는 과정을 제 안하였다. 연구의 세부 과정 및 결과는 다음과 같다.

1. 시니어의 평발 발생빈도를 살펴보기 위해, 60 대 이상 남성의 제6차 사이즈코리아 $3 \mathrm{D}$ 발 스캔 데이터 로부터 발바닥 유형을 분류하였다. $3 \mathrm{D}$ 발 스캔 데이 터에서 발바닥 수평단면도를 추출하여 발아치 유형을 분석한 결과, 정상발 139 명 $(73.5 \%)$, 평발 50 명 $(26.5 \%)$, 오목발 0 명 $(0.0 \%)$ 으로 분류되었다.

2. 정상발과 평발 유형의 대표피험자를 20 명씩 선 정하고, 발바닥 곡면에 9 개의 수직기준선과 144 개의 포인트를 설정한 후, $3 \mathrm{D}$ 좌표 $(\mathrm{X}, \mathrm{Y}, \mathrm{Z})$ 를 측정하고 그 경향을 분석하였다.

3. 시니어 평발 남성에게 부족한 발아치 굴곡을 추 가하기 위해 평발의 발바닥 곡면에 정상발의 발바닥 곡면을 중합하여 평발용 인솔을 $3 \mathrm{D}$ 모델링하였다. 제 작된 $3 \mathrm{D}$ 인솔 모델은 평발에 필요한 발아치 및 발가 락 부위에 정상발의 곡률을 제공할 수 있었다.

4. 모델링된 시니어 평발용 인솔을 $3 \mathrm{D}$ 프린터로 출 력하였다. 다양한 $3 \mathrm{D}$ 프린터의 사출 재료 중 인솔에 적합한 연성 아크릴계 레진으로 출력하였다. 출력한 인솔은 고무와 같은 탄성이 있어 휘어짐이 가능하고, 출력 후에 신발에 넣어 착용할 수 있었다.

본 연구는 $3 \mathrm{D}$ 스캔데이터를 이용하여 발아치 유형 을 분류함으로써 자동계측 프로그램이 수집하지 못 하는 발아치 곡면의 정보 분석 방법을 제시하였다. 또한, $3 \mathrm{D}$ 좌표데이터를 계측하여 형상을 정량화하여 활용하는 방안을 제시하였다. $3 \mathrm{D}$ 스캔 데이터는 다양
한 정보를 가지고 있는 데이터로, 연구 목적에 맞게 다양하게 활용할 수 있다는 점을 시사하고 있다. 평발 과 정상발의 형상 차이를 인솔 곡면에 적용한 본 연 구의 $3 \mathrm{D}$ 시스템 제작 프로세스는 새로운 제품시장의 확대가 가능할 것으로 보이며, 시니어 평발을 위한 인솔뿐 아니라 다양한 연령과 발 유형을 위한 맞춤형 인솔 제작에 적용 가능할 것으로 여겨진다.

본 연구에서 발바닥 밑면뿐 아니라 측면을 모두 감 싸는 일체형 인솔을 제작하였으나, 이는 신발의 종류 및 디자인에 따라 다양하게 호환되지 못하여 제품 착 용 시 한계가 있다. 또한 출력 인솔에 대한 착화 테스 트가 이루어지지 않아, 그 효용성 검증에 대한 추가 연구가 필요한 것으로 여겨진다. 후속연구에서는 발 바닥의 불편 부위의 개별 문제점에 집중하여 탈부착 이 가능한 부분 인솔을 제작하여 그 효과를 검증하면 활용도가 높을 것으로 보인다.

\section{References}

Benedict. (2016, September 11). Custom 3D printed insoles from Phits help athletes recover from injury. 3D Printing Applications in 3Ders.org, Retrieved February 18, 2017, from http://www.3ders. org/articles/20160911-custom-3d-printed-insoles-f rom-phits-help-athletes-recover-from-injury.html

Benedict. (2017, February 8). 3D printed insole startup Wiivv wearables looking well-heeled: $\$ 4 \mathrm{M}$ raised, competitor eSoles acquired. $3 D$ Printing Applications in 3Ders.org, Retrieved February 18, 2017, from http://www.3ders.org/articles/201702083d-printed-insole-startup-wiivv-wearables-lookingwell-heeled-4m-raised-competitor-esoles-acquired. html 
Butdee, S., \& Tangchaidee, K. (2008). Formulation of 3D shoe sizes using scanning camera and CAD modelling. Journal of Achievements in Materials and Manufacturing Engineering, 31(2), 449-455.

Choi, J. I. (2015). Development of design technique of Korean standard last for production of healthyfunctional shoes. Unpublished doctoral dissertation, Pusan National University, Busan, Korea.

Choi, S. H. (2005). Foot shape classifying of women in Korea with $3 D$ foot scan data. Unpublished doctoral dissertation, Yonsei University, Seoul, Korea.

Coughlin, M. J., \& Kaz, A. (2009). Correlation of Harris Mats, physical exam, pictures, and radiographic measurements in adult flatfoot deformity. Foot \& Ankle International, 30(7), 604-612. doi: 10.3113/FAI.2009.0604

Flatfoot. (n.d.). In Seoul National University Hospital, Medical Information. Retrieved February 12, 2017, from http://terms.naver.com/entry.nhn?docId $=926772 \&$ cid $=51007 \&$ categoryId $=51007$

How 3D printing impacts PUMA and Reebok. (2013, March 8). 3D Printer and $3 D$ Printing News, Retrieved February 18, 2017, from http://www.3ders. org/articles/20130308-how-3d-printing-impacts-pu ma-and-reebok-in-designing-and-prototyping.html

Jang, S. E. (2012). 슈즈디자인과 패턴메이킹 [Shoes design and patternmaking]. Paju: Kyomunsa.

Kang, H.-S. (2012). Foot deformity measurement validity: The relationship between CSI, SAI, RCSP. Unpublished master's thesis, Ewha Womans University, Seoul, Korea.

Kim, E.-H. (2003). The impact that the exercise influence on the foot form and footprint. Unpublished master's thesis, Daejeon University, Daejeon, Korea.

Kim, G. Y. (2001). A study on the shape of women's foot arches. Unpublished doctoral dissertation, Kyung Hee University, Seoul, Korea.

Kim, J. H. (2015). Development of foot-measuring toolkit and modeling process for designing cus- tomized round toe midsole with $3 D$ printing technology. Unpublished master's thesis, Yonsei University, Seoul, Korea.

Kim, K.-H. (2011). Biomechanical analysis of arch support devices on normal and low arch. Unpublished master's thesis, Kyungsung University, Busan, Korea.

Kim, N. S. (2013). A study on foot shape and shoe sizing system for the elderly. Unpublished doctoral dissertation, Chonnam National University, Gwangju, Korea.

Kim, Y.-D. (2015). A case study on the development of insloes for seniors in preparation for aged society. Unpublished master's thesis, Hanbat National University, Daejeon, Korea.

Korean Agency for Technology and Standards. (2012). Sizing system for shoes (KS M 6681 : 2007, 2012 confirmed). Gwacheon: Korean Agency for Technology and Standards.

Korean Agency for Technology and Standards. (2014). Assembly middle insole of shoes (KS G 3406 : 1994, 2014 confirmed). Gwacheon: Korean Agency for Technology and Standards.

Lee, J.-E., \& Kwon, Y.-A. (2008). The classification of men's foot shape according to age. Fashion \& Textile Research Journal, 10(5), 644-651.

Lee, J. Y. (2004). The investigation of the shoe-last size classification system for Korean adults with $3 D$ foot-scanner. Unpublished doctoral dissertation, Hanyang University, Seoul, Korea.

Lee, Y.-C., Lin, G., \& Wang, M.-J. J. (2014). Comparing $3 \mathrm{D}$ foot scanning with conventional measurement methods. Journal of Foot and Ankle Research, 7:44. doi:10.1186/s13047-014-0044-7

Lee, Y.-J., Oh, M.-H., Kim, G.-Y., Nam, G.-W., Paek, H.-H., \& Kim, J.-J. (2007). The relationship of balance and walking with prefered type of shoes in the elderly. The Journal of Occupational Therapy for the Aged and Dementia, 1(1), 30-37.

Leem, Y. M., Bang, H. K., \& Shin, K. J. (2007). Foot classification for manufacturing of comfortable 
shoes. Journal of the Korean Society of Safety, 22(6), 81-86.

Lim, H. S. (2016). 3D printed midsole design according to the sole types of elementary school students. The Research Journal of the Costume Culture, 24(3), 315-323. doi:10.7741/rjcc.2016.24.3.315

Min, S. N., Cho, J. Y., Park, S. J., Subramaniyam, M., Kim, S. E., \& Lee, K. S. (2016, June). 아치 에어쿠션이 장착된 기능성 인솔에 대한 인간공학 적 평가 [Ergonomic evaluation of functional insole with arch air cushion]. Proceedings of Spring Conference of the Ergonomics Society of Korea and 18th Korea - Japan Joint Symposium, jejudo, 543-546.

Murley, G. S., Menz, H. B., \& Landorf, K. B. (2009). A protocol for classifying normal- and flat-arched foot posture for research studies using clinical and radiographic measurements. Journal of Foot and Ankle Research, 2:22. doi:10.1186/1757-1146$2-22$

Oh, H. K., \& Kim, H. G. (2013). A study on the computerization of the shoe last manufacturing for customized handmade shoes: Focused on the data formation through a 3-Dimensional scanner. Journal of Digital Design, 13(2), 29-36.

Oh, S.-Y., Suh, D.-A., \& Kim, H.-G. (2016). Last design for men's shoes using $3 \mathrm{D}$ foot scanner and 3D printer. The Journal of the Korea Contents Association, 16(2), 186-199. doi:10.5392/JKCA. 2016.16.02.186

Park, J.-K. (2005). Classification of foot types for shoes size system of elderly women. Journal of the Korean Society of Costume, 55(2), 33-44.

Park, J. Y., Kim, Y. K., Kim, M. H., Lee, S. J., Kim, M. W., \& Kim, Y. C. (2009, June). Comparative analysis of $3 \mathrm{D}$ foot scan method and 3D laser scan method for development of custom-made insole. Proceedings of Korean Society for Precision Engineering (KSPE) 2009 Spring Conference, Jeju-do, 969-970.

Phits. (2016, August 24). Phits at the Rio Olympics, Retrieved March 10, 2017, http://www.phits.be/en/ phits-rio-olympics

Phits. (n.d.a). About Phits insoles. Retrieved March 10, 2017, http://www.phits.be/en/about-phits-insoles Phits. (n.d.b). Phits expert workflow - from scan to insoles. Retrieved March 10, 2017, http://www.phits. be/en/phits-expert-workflow-scan-insoles

Seok, H.-J., \& Park, J.-E. (2007). The classification of elderly men's feet: With the three-dimensional body scanner data of Size Korea. Journal of the Korean Society of Costume, 57(10), 50-59.

Shi, N., Yi, S., Xiong, S., \& Jiang, Z. (2009, April). A CAD system for shoe last customization. Proceedings of 2009 International Joint Conference on Computational Sciences and Optimization (CSO 2009), Hainan, 1, 957-960. doi:10.1109/CSO.2009. 229

Song, S. J., \& Kim, S. H. (2004). A study on surface flattening for 3 dimensional shoe pattern design. Korean Journal of Computational Design and Engineering, 9(3), 266-275.

Song, E. Y., Kim, K. T., Kim, S.-H., \& Lee, S. Y. (2016). Individual customized insole model. The Journal of Korea Institute of Information, Electronics, and Communication Technology, 9(4), 323-329. doi:10.17661/jkiiect.2016.9.4.323

Xiong, S., Zhao, J., Jiang, Z., \& Dong, M. (2010). A computer-aided design system for foot-feature-based shoe last customization. The International Journal of Advanced Manufacturing Technology, 46 (1), 11-19, doi:10.1007/s00170-009-2087-7 